\title{
AİLE İÇİNDE YAŞANAN ANLAŞMAZLIKLAR: EBEVEYNLERIN VE ÇOCUKLARIN GÖRÜŞLERİ
}

\author{
DISAGREEMENTS WITHIN THE FAMILY: VIEWS OF PARENTS AND CHILDREN
}

\author{
Fatih CAMADAN ${ }^{1}$ - Zeki KARATAŞ⿻ ${ }^{2}$ - Sakine BOZALi ${ }^{3}$
}

\section{$\ddot{O} \mathbf{z}$}

Bu çalışmanın amacı aile içinde yaşanan anlaşmazlıkları ve bu anlaşmazlıklar karşısında ortaya koyulan tepkileri; sorunu doğrudan deneyimleyen anne, baba ve çocukların öznel bakış açısıyla anlamaya çalışmaktır. Aile içi ilişkileri deneyimleyen katılımcılarla derinlemesine görüşmelerin yapıldığı bu araştırmada, nitel araştırma yaklaşımına dayalı durum tespiti niteliğinde betimsel bir çalışma gerçekleştirilmiştir. Bu kapsamda 10 evli çift ve bu çiftlerin birer çocukları (5 kı ve 5 erkek) olmak üzere toplam 30 kişiyle yüz yüze görüşmeler yapılmıştır. Görüşmelerde çocuklar ve anne-babalar için tasarlanan yarı yapılandırılmış görüşme formları kullanılmıştır. Katılımcılardan elde edilen veriler içerik analizine tabi tutularak kodlanmış ve bu kodlar ortak temalar altında sınıflandırılmıştır. Araştırmadan elde edilen sonuçlara göre toplumun en küçük sosyal birimi olan ailede; çocuklarla ilgili konular, olumsuz alışkanlıklar, tercihlerin farklı olması ve sorumlulukların aksatılması konularında anlaşmazlıklar yaşandığı ve bu anlaşmazlıklar karşısında aile bireylerinin uzlaşmacı tepkiler yerine, saldırgan ve kaçınmacı tepkiler ortaya koydukları görülmüştür. Bu nedenle aile üyelerinin doğru ve etkili iletişim becerileri geliştirebilmeleri için psiko-sosyal açıdan desteklenmelerinin gerektiği anlaşılmıştır.

Anahtar Kelimeler: Aile, Aile İçi Anlaşmazlıklar, Ebeveyn, Çocuk

\begin{abstract}
The aim of this study is to comprehend the disagreements arising in a family and reactions to these disagreements from a subjective perspective of mothers, fathers, and children ( 5 female and 5 male) who directly experience the problem. The present study, in which in-depth interviews were conducted with participants who have experienced family relationships, is a descriptive study based on qualitative research approach. Within this scope, face-to-face interviews were conducted with a total of 30 people including 10 married couples and their children. In the interviews, semi-structured interview forms developed for children and parents were used. The data obtained from the participants were coded by content analysis and these codes were classified under the common themes. According to the study results, members of a family, which is the smallest social unit of the society, have disagreements over children's issues, negative habits, have different preferences and interruption of responsibilities and they provoke aggressive and avoidant reactions rather than reconciliatory reactions against these disagreements. Therefore, it is seen that family members need to be psycho-socially supported so that they can develop accurate and effective communication skills.
\end{abstract}

Keywords: Family, Disagreements in the Family, Parent, Children

\footnotetext{
${ }^{1}$ Yrd.Doç.Dr., Recep Tayyip Erdoğan Üniversitesi, Eğitim Fakültesi, fatih.camadan@ hotmail.com

${ }^{2}$ Yrd.Doç.Dr., Recep Tayyip Erdoğan Üniversitesi, İktisadi ve İdari Bilimler Fakültesi, zeki.karatas@erdogan.edu.tr

${ }^{3}$ Milli Eğitim Bakanlığı, Başköy İlkokulu ve Ortaokulu, sakinebozali61@ gmail.com
} 


\section{GíRiş}

Postmodern çağda aile, işlevlerinden bazılarını diğer sosyal kurumlara devretmiş görünse de çocukların bakımı, yetiştirilmesi, ilk eğitimi, sosyalleşmesi ve eşler arası ilişkilerin düzenlenmesi gibi pek çok işlevi nedeniyle varlığını ve önemini devam ettirmektedir. Ancak aile üyelerinden ya da sosyal çevreden kaynaklanan bir takım yetersizlikler, aileyi işlevsiz hale getirmekte ve üyelerinin problem çözme yeteneklerini olumsuz yönde etkilemektedir. Bununla birlikte aile yapısının sağlıksız olması sadece kendi üyelerinin değil, sosyal çevre ve toplumun da dengesini bozmaktadır. Günümüzde suça sürüklenme, madde kullanımı, çocuk ihmali ve istismarı gibi pek çok sosyal sorunun altında sağlıklı bir şekilde işlevlerini yerine getiremeyen aile yapısının olduğu düşünülmektedir.

Kültürden kültüre farklılık gösterse de yapılan açıklamalar sağlıklı ailelerin birtakım ortak özelliklere sahip olduğunu göstermektedir. İlişkilerin açık iletişim ve güven üzerine kurulduğu, değişime uyum sağlama konusunda sınırların esnek olduğu, üyelerin özerkliğinin desteklendiği, çocukların sorumluluk alma konusunda teşvik edildiği ve geleceğe dair iyimserliğe sahip ailelerin sağlıklı olduğu vurgulanmaktadır (Nazlı, 2001). Aile içinde yaşanan anlaşmazlıklar ise aile işlevlerinin sağlıklı bir şekilde yerine getirilmesini engellemekte, başta çocuklar olmak üzere aile üyelerinin ruh sağlı̆̆ını olumsuz yönde etkilemektedir (Cummings ve Davies, 2002; El-Sheikh, Buckhalt, Mark Cummings ve 2007; Krishnakumar ve Buehler, 2000; Maccoby ve Martin, 1983; McCoy, George, Cummings, ve Davies, 2013). Ailenin sağlıklı olarak işlevde bulunması ise süreklilik ve değişim konularında dengeyi kurabilme kapasitesine bağlıdır. Aile içerisinde sınırları belirlenmiş bir otoriteye ihtiyaç duyulmakla birlikte, otoriteye bağlı hiyerarşinin gerekli olduğu zamanlarda esnekliği sağlayabilecek yapının da olması gerekmektedir. Ailenin sağlıklı olarak işlevde bulunmasını sağlayacak bir diğer özellik, birliktelik boyutunda aile üyelerinin özerklik ve bağlılık ihtiyaçlarının dengeli bir şekilde karşılanmasıdır. Çoklu aile sistemi modeline göre; birliktelik ve esneklik boyutunda dengeli olan ailelerin açık ve etkili iletişim becerileri oldukça iyi düzeydedir. Aile üyeleri birbirlerini empatiyle dinler, duygularını doğrudan paylaşır, sorunlara odaklanarak bunları etkin bir şekilde çözer ve fikir ayrılıklarına saygı duyarlar (Worden, 2013; Olson, Sprenkle ve Russell, 1979).

Aile içi ilişkileri değerlendiren çalışmalar incelendiğinde; aile işlevleri (Kocayörük, 2010), aile katılımı (Keçeli-Kaysıl1, 2008), aile ilişkileri (Demirtaş-Zorbaz ve Korkut-Owen, 2013), aile yılmazlığı (Kaner ve Bayrakl1, 2010), aile aidiyeti (Mavili, Kesen ve Daşbaş, 2014), aile içi şiddet (Babahanoğlu ve Özdemir, 2016; Başoğul, Lök ve Öncel, 2017), evlilik doyumu (Çağ ve Yıldırım, 2013; Yıldız ve Baytemir, 2016), ebeveyn kontrolü (Ayçiçeği Dinn ve Caldwell-Harris), evlilik çatışması (Güven ve Erden, 2014) ve evlilik uyumu (Özer ve CihanGüngör, 2012; Soylu ve Kağnıc1, 2015; Tutarel-Kışlak ve Çavuşoğlu, 2006) gibi kavramlar üzerinden konunun ele alındığı görülmektedir. Tüm bu çalışmaların sonuçlarında aile içi ilişkilerde bireylerin doyum sağlaması ve mutlu olmasının aile yapısının sağlıklı olmasıyla yakından ilişkili olduğu belirlenmiştir.

Ebeveyn-çocuk ilişkisinin anne-baba ve çocuğun kişilik özelliklerinden, anne-babanın kök ailesiyle ve kendi aralarındaki ilişkiden, içinde yaşadıkları fiziksel ve sosyal çevreden sağlanan destekten etkilendiği bilinmektedir (Hortaçsu, 2015). Ancak bu çalışmada daha çok aile içinde yaşanan anlaşmazlıkların aileye etkisini anlamaya yönelik görüşler üzerinde durulmuştur. Aile içinde yaşanan anlaşmazlıkların nedenlerinin bilinmesi ve aile üyelerinin bu anlaşmazlıklarda ne tür tepkiler verdiklerinin ortaya çıkarılması, ailelere yönelik psiko-sosyal destek hizmetleri sunan ve aile içi ilişkilere müdahalede bulunan pek çok meslek ve disiplin açısından önemlidir. Dolayısıyla bu çalışmanın temel amacı; aile içinde yaşanan anlaşmazlıkları ve bu anlaşmazlıklar karşısında ortaya koyulan tepkileri sorunu doğrudan 
deneyimleyen anne, baba ve çocukların öznel bakış açısıyla anlamaya çalışmaktır. Bu bağlamda araştırma kapsamında şu sorulara cevap aranmıştır:

1) Eşler arasında hangi konularda anlaşmazlıklar yaşanmaktadır?

Yaşanan bu anlaşmazlıklarda eşlerin tepkileri nasıl olmaktadır?

2) Anne-baba-çocuk arasında hangi konularda anlaşmazlıklar yaşanmaktadır?

Yaşanan bu anlaşmazlıklarda anne-baba-çocuğun tepkileri nasıl olmaktadır?

\section{YÖNTEM}

$\mathrm{Bu}$ bölümde araştırmanın modeli, çalışma grubu, veri toplama araçları, verilerin toplanması ve verilerin analizine yer verilmiştir. Ayrıca araştırmanın geçerlik ve güvenirliğine ilişkin bilgiler sunulmuştur.

$\mathrm{Bu}$ araştırmada temel olarak aile içinde yaşanan anlaşmazlıklar ve bu anlaşmazlıklar karşısında ortaya konulan tepkiler doğrudan anne, baba ve çocukların görüşleri incelenerek belirlenmeye çalışılmıştır. Bu amaç doğrultusunda aile içerisinde eşler arasında, anne-baba ve çocuk arasında hangi konularda anlaşmazlıklar yaşandığ 1 ve yaşanan bu anlaşmazlıklarda aile üyelerinin nasıl tepkiler verdikleri incelenmiştir.

\section{Araştırmanın Modeli}

$\mathrm{Bu}$ araştırmada aile içinde yaşanan anlaşmazlıklar ve bu anlaşmazlıklar karşısında ortaya koyulan tepkiler belirlenmeye çalışılmıştır. Bu amaç doğrultusunda aile içerisinde eşler arasında, anne-baba ve çocuk arasında yaşanan anlaşmazlıkların nedenlerine ilişkin aile üyelerinin görüssleri ve bu durumlarda verdikleri tepkiler incelenmiştir. Değinilen durumların saptanması amacıyla yapılan bu araştırma nitel araştırma yaklaşımına dayalı olup durum tespiti niteliğinde betimsel bir çalışmadır. Nitel araştırmalar görüşme, gözlem ve doküman analizi gibi yöntemlerin kullanılarak algı ve olaylara ilişkin verilerin nitel yollarla toplandığ ve yorumlandığı araştırmalar olarak açıklanmaktadır (Yıldırım ve Şimşek, 2008). Bu araştırmada da katılımcıların aile içerisinde yaşanan anlaşmazlıklara ilişkin görüşleri betimlenmeye çalışılmıştır.

\section{Çalışma Grubu}

Araştırmanın çalışma grubu, 10 evli çift ve bu çiftlerin birer çocukları olan 5 kız ve 5 erkek olmak üzere toplam 30 kişiden oluşmaktadır. Çalışma grubunun belirlenmesinde ölçüt olarak en az bir çocuğu olan aileler tercih edilmiştir. Bu ölçütün dikkate alınmasının nedeni hem eşlerin kendi aralarında hem de çocukları ile yaşayabilecekleri sorunların nedenlerine ilişkin görüşleri ve bu durumlarda ne tür tepkiler verdiklerinin ortaya çıkarılmasının amaçlanmasıdır. Ebeveynlerin yaşları 25 ile 45 arasında; çocukların yaşları ise 6 ile 13 arasında değişmektedir. Anne babaların meslekleri incelendiğinde; annelerin ev hanımı ( $\mathrm{f}=9$ ) ve hizmetli $(\mathrm{f}=1)$; babaların ise inşaat işçisi $(\mathrm{f}=6)$, imam $(\mathrm{f}=2)$, şoför $(\mathrm{f}=1)$ ve camc1 $(\mathrm{f}=1)$ olduğu anlaşılmaktadır. Ayrıca çocuklar 1. sınıf $(\mathrm{f}=1), 2 \cdot \sin ı \mathrm{f}(\mathrm{f}=2), 3 \cdot \sin ı \mathrm{f}(\mathrm{f}=2), 4 \cdot \sin ı \mathrm{f}(\mathrm{f}=1), 5$. sinıf $(\mathrm{f}=1), 6 . \sin 1 \mathrm{f}(\mathrm{f}=1), 7$. $\sin ı \mathrm{f}(\mathrm{f}=1)$ ve 8 . sinıfta $(\mathrm{f}=1)$ öğrenim görmektedirler.

\section{Veri Toplama Araçları}

Çalışmada veri toplama araçları olarak araştırmacılar tarafından geliştirilen yarı yapılandırılmış görüşme formları kullanılmıştır. Görüşme formları öncelikle beş çift ve bu çiftlerin birer çocukları olmak üzere toplam 15 kişi ile pilot olarak uygulanmıştır. Pilot uygulama sonucunda elde edilen bu formlar psikolojik danışmanlık ve rehberlik alanında uzman olan üç araştırmacı tarafından incelenmiştir. Uzmanların değerlendirmeleri doğrultusundan görüşme formlarına son hali verilmiştir. Uygulanan görüşme formları anne ve 
babalar için bir form (Ek 1) çocuklar için ayrı bir form (Ek 2) şeklindedir. Anne ve babalar için hazırlanan görüşme formu; iki temel ve birer alt soru olmak üzere toplam dört sorudan oluşmaktadır. Çocuklar için hazırlanmış görüşme formu da bir temel ve bir alt soru olmak üzere toplam iki sorudan oluşmaktadır.

\section{Verilerin Toplanması}

Araştırmanın verilerinin toplanmasında, görüşmeler gerçekleştirilmeden önce katılımcılara araştırmanın amacı hakkında kısaca bilgiler verilmiş ve daha sonra uygulamalara geçilmiştir. Araştırmada 10 anne, 10 baba ve 10 çocuk olmak üzere toplamda 30 görüşme yapılmıştır. Her bir uygulama yaklaşık olarak 20 dakika sürmüştür. Verilerin toplanması amacıyla yapılan görüşmeler, araştırmacılar tarafından soruların okunması ve cevapların yine araştırmacılar tarafından yazılı olarak kaydedilmesi şeklinde gerçekleştirilmiştir. Anne, baba ve çocuklarla gerçekleştirilen görüşmelerin sonucunda kaydedilen görüşme formları numaralandırılmıştır. Bu sayede hangi formun hangi katılımcıya ait olduğunu görebilmek mümkün olmuştur.

\section{Velilerin Analizi}

Verilerin analizine ilişkin gerçekleştirilen süreçler aşağıda ayrıntılı şekilde açıklanmıştır. Öncelikle görüşme formları katılımcıların, anne, baba ya da çocuk olma durumlarına göre sınıflandırılmıştır. Formlara anneler için "A", babalar için "B" ve çocuklar için "Ç" harfleri ile başlayan numaralar verilmiştir. Değinilen numaralar verilirken aynı aileden olan anne, baba ve çocuk için aynı numaranın kullanılmasına dikkat edilmiştir. Yani bir aile içerisindeki anne için "A1", baba için "B1" ve çocuk için "Ç1" ifadesi kullanılmıştır. Numaralar sıralanırken herhangi bir kriter gözetilmemiştir. Bu şekilde bir sınıflandırma tercih edilmesinin nedeni ise "Bulgular" bölümünde sunulan katılımcı ifadelerinin kime ait olduğunun görülmesini sağlamaktır.

Araştırmada elde edilen verilerin analizinde içerik analizi tekniği kullanılmıştır. Berg ve Lune (2015) içerik analizini; "kalıpları, temaları, önyargılarl ve anlamları tespit etmek amactyla belirli bir materyalin dikkatlice, ayrintıl ve sistematik olarak incelenmesi ve yorumlanması" olarak tanımlamışlardır. İçerik analizinde veriler dört aşamada analiz edilmektedir. Bu aşamalar; 1. verilerin kodlanması, 2. temaların bulunması, 3. kodların ve temaların düzenlenmesi ve 4 . bulguların tanımlanması ve yorumlanması şeklindedir (Yıldırım ve Şimşek, 2008). Bu araştırmada da içerik analizi yapılırken değinilen aşamalar izlenmiştir. Öncelikle katılımcılardan elde edilen veriler dikkatli bir şekilde incelenmiş ve bu verilerden benzer içerikte olanlar belli kodlar altında gruplandırılmıştır. Kodlar oluşturulurken katılımcıların ifadelerinin orijinal hallerine sadık kalınmaya özen gösterilmiştir (1. aşama). Belirlenen bu kodlardan benzer içerikte olanlar için ise çeşitli temalar oluşturulmuştur (2. aşama). Verilerin anlaşılır bir şekilde ortaya koyulması amacıyla kod ve temalar düzenlenerek frekanslar eşliğinde tablolaştırılmıştır. Böylece kod ve temaların içinde kaç katılımcının ifadesinin yer aldığı açık bir şekilde ortaya koyulmuştur. Bu işlem ayrıca, ortaya çıkan kod ve temalar arasında karşılaştırma olanağı da vermektedir (3. aşama). Analiz edilen ve tablolaştırılan katılımcı ifadeleri değinilen kod ve temalar dikkate alınarak yorumlanmıştır (4. aşama).

\section{Geçerlik ve Güvenirlik}

Geçerlik: Nitel araştırmalarda geçerlik, araştırmacının ortaya koyduğu kategori ve yorumların gerçekle örtüşüp örtüşmediği olarak ifade edilir (Creswell, 2013). Manning (1997), nitel araştırmalarda geçerliğin sağlanması için uzun süreli görüşme, uzman görüşü ve katılımcıların onayı gibi bir takım ölçütlerin olduğunu belirtmiştir. Yukarıda değinilen ölçütler araştırma kapsamında sağlanmaya çalışılmıştır. Uzun süreli görüşme ölçütünü sağlamak için 
araştırmada birincil veri kaynakları olan anne, baba ve çocuklarla mümkün oldukça beraber zaman geçirilmiş ve katılımcılar ayrıntılı şekilde tanınmaya çalışılmıştır. Ayrıca verilerin toplanmasında katılımcılarla yapılan görüşmeler doğrudan araştırmacılar tarafından gerçekleştirilmiş, görüşmeler öncesinde araştırmanın amacıyla ilgili gerekli açıklamalar yapılmış, katılımcıların soruları dikkate alınmış ve ardından görüşmelere başlanmıştır. Diğer bir ölçüt uzman görüşüne başvurulmasıdır. $\mathrm{Bu}$ kapsamda; görüşme formlarının oluşturulmasında psikolojik danışmanlık ve rehberlik alanında uzman olan üç araştırmacının görüşlerine başvurulmuştur. Geçerliğin sağlanmasında dikkate alınan diğer bir ölçüt de katılımcıların onayının alınmasıdır. Bu amaçla katılımcıların ifadelerinin analizi sürecinde; araştırmacıların kod ve temaları belirlerken kararsız kaldıkları durumlarda yeniden katılımcılarla görüşülmüş ve kullandıkları ifadenin içeriği daha açık bir şekilde anlamlandırılmaya çalışılmıştır.

Nitel araştırmalarda geçerlikle ilgili olarak Yıldırım ve Şimşek (2008), araştırmacının okuyucuyu süreçler hakkında detaylı şekilde bilgilendirmesinin önemli olduğunu vurgulamıştır. Böylece okuyucuya araştırma sonuçlarını kendi ortamına yansıtabilme firsatı sunulmaktadır. Bu noktada araştırmanın geçerliğini artırmak amacıyla verilerin toplanması, analizi ve yorumlanması süreçleri ayrıntılı şekilde paylaşılmıştır. Bu sayede okuyuculara elde edilen sonuçları değerlendirerek kendi durumlarına aktarabilme firsatı sunulmuştur. Nitel araştırmalarda geçerliğin sağlanması amacıyla yapılan diğer bir uygulama, görüşülen bireylerin ifadelerinden doğrudan alıntılara yer vermektir (Yıldırım ve Şimşek, 2008). Bu araştırma kapsamında da katılımcıların ifadelerinden bazıları örnekler olarak sunulmuştur. Araştırmada geçerliğin bu sayede sağlandığı düşünülmüş̧ür. Yukarıda değinilen uygulamalarla araştırmanın geçerliği için dikkate alınması gereken ölçütler karşılanmaya çalışılmıştır.

Güvenirlik: Creswell (2013), nitel araştırmaların güvenirliğinin sağlanmasında verilerin analizi için çoklu kodlayıcıların bulunmasını ve bu kodlayıcıların değerlendirmeleri arasında tutarlılığın olması gerektiğini vurgulamaktadır. Bu bilgiler kapsamında güvenirliğin sağlanıp sağlanmadığının anlaşılması amacıyla araştırmada elde edilen görüşme psikolojik danışmanlık alanında uzman olan bir araştırmacıya değerlendirmesi amacıyla iletilmiştir. Uzmandan görüşme formlarındaki ifadelerden kod ve temalar oluşturması istenmiştir. Daha sonra uzmanın oluşturduğu kod ve temalarla araştırmacıların oluşturdukları karşılaştırılmıştır. İki sonucun karşılaştırılmasında Miles ve Huberman'ın (1994) formülü [Güvenirlik = görüş birliği puanı / (görüş birliği puanı + görüş ayrılığı puan1)] kullanılmıştır. Bu formül sonucunda elde edilen güvenirlik değerinin .70'nin üzerinde olması yeterli görülmektedir. Bu formül öncelikle temalar için hesaplanmıştır. Elde edilen değerler şu şekilde bulunmuştur: $[.85=24 /(24+4)]$. Bu formül kodlar için de hesaplanmıştır. Elde edilen değerler şu şekildedir: $[.88=90 /(90+12)]$. Yukarıda yapılan hesaplamalar sonucunda araştırmacılar ve uzmanın oluşturdukları tema ve kodların birbiriyle örtüştüğü anlaşılmıştır. Araştırmada güvenirlik bu şekilde sağlanmaya çalışılmıştır.

\section{BULGULAR}

$\mathrm{Bu}$ bölümde anne, baba ve çocuklarla yapılan görüşmeler sonucunda elde edilen veriler analiz edilmiş ve oluşturulan kodlar ve temalar tablolar halinde sunulmuştur. Ayrıca katılımcıların görüşleri, kullandıkları ifadelerden yapılan doğrudan alıntılarla aktarılmıştır. Araştırmanın bulguları, anne ve babalarla yapılan görüşmeler sonucundan elde edilen ve çocuklarla yapılan görüşmeler sonucunda elde edilen bulgular olmak üzere iki başlık altında sunulmuştur. 


\section{A. Anne-Babalarla Yapılan Görüşmeler Sonucunda Elde Edilen Bulgular}

\section{Eşler Arasında Yaşanan Anlaşmazlık}

Araştırma kapsamında "Eşinizle hangi konularda anlaşmazlık yaşarsınız?” sorusuna verilen cevaplara ilişkin elde edilen bulgular frekanslar eşliğinde Tablo 1'de sunulmuştur.

Tablo 1. "Eşinizle hangi konularda anlaşmazlık yaşarsınız?" sorusuna verilen cevaplar doğrultusunda oluşturulan kodlar ve temalar

\begin{tabular}{|c|c|c|c|c|}
\hline \multirow[t]{2}{*}{ Tema } & \multirow[t]{2}{*}{ Kodlar } & \multicolumn{3}{|c|}{ Katılımcı } \\
\hline & & $\begin{array}{c}\text { Anne } \\
\text { (f) }\end{array}$ & $\begin{array}{c}\text { Baba } \\
\text { (f) } \\
\end{array}$ & $\begin{array}{c}\text { Toplam } \\
\text { (f) }\end{array}$ \\
\hline \multirow{5}{*}{ Çocuklarla İlgili Konular } & $\begin{array}{l}\text { Çocukların eğitimi ile } \\
\text { ilgilenmeme }\end{array}$ & 2 & 3 & 5 \\
\hline & Çocuklara bağırma & 2 & 3 & 5 \\
\hline & Çocukları şımartma & 2 & 1 & 3 \\
\hline & Çocukları dövme & 2 & & 2 \\
\hline & Çocuklara çok ders çalıştırma & & 1 & 1 \\
\hline Toplam & & 8 & 8 & 16 \\
\hline \multirow{5}{*}{ Olumsuz Alışkanlıklar } & Savurgan olma & 3 & 1 & 4 \\
\hline & Sigara içme & 2 & 2 & 4 \\
\hline & İnternette fazla zaman geçirme & & 1 & 1 \\
\hline & Temiz olmama & & 1 & 1 \\
\hline & İnatlaşma & & 1 & 1 \\
\hline Toplam & & 5 & 6 & 11 \\
\hline \multirow{3}{*}{ Tercihlerin Farkl1 Olması } & Kiyafet tercihleri & 2 & 1 & 3 \\
\hline & Gezme tercihleri & 2 & 1 & 3 \\
\hline & TV'de izlenen programlar & & 1 & 1 \\
\hline Toplam & & 4 & 3 & 7 \\
\hline \multirow{2}{*}{$\begin{array}{l}\text { Sorumlulukların } \\
\text { Aksatılması }\end{array}$} & Eve geç gelme & 1 & 1 & 2 \\
\hline & Ev işlerine yardım etmeme & 1 & & 1 \\
\hline Toplam & & 2 & 1 & 3 \\
\hline
\end{tabular}

Tablo 1'de görüldüğü üzere katılımcıların verdikleri cevaplara dayalı olarak 15 farklı kod belirlenmiştir. Bu kodların dört farklı tema içerisinde yer alabileceği anlaşılmıştır. Belirtilen kodlar ve temalarla ilgili detaylar aşağıda ayrıntılarıyla sunulmuştur.

Katılımcıların verdikleri cevaplardan elde edilen kodlar; çocukların eğitimi ile ilgilenmeme $\left(f_{A}=2, f_{B}=3\right)$, çocuklara bağırma $\left(f_{A}=2, f_{B}=3\right)$, çocukları şımartma $\left(f_{A}=2, f_{B}=1\right)$, çocukları dövme $\left(f_{A}=2\right)$ ve çocuklara çok ders çalıştırma $\left(f_{B}=1\right)$ şeklindedir. $B u$ kodlar çocuklarla ilgili içerikte olduğundan, çocuklarla ilgili konular $\left(\mathrm{f}_{\mathrm{A}}=8, \mathrm{f}_{\mathrm{B}}=8\right)$ teması altında toplanmıştır. Bunun yanında katılımcıların bu soruya; savurgan olma $\left(f_{A}=3, f_{B}=1\right)$, sigara içme $\left(f_{A}=2, f_{B}=2\right)$, internette fazla zaman geçirme $\left(f_{B}=1\right)$, temiz olmama $\left(f_{B}=1\right)$ ve inatlaşma $\left(f_{B}=1\right)$ gibi cevaplar verdikleri görülmüştür. Bu ifadelerin bir takım istenmeyen davranışları içerdiği görülmüş ve olumsuz alışkanlıklar $\left(\mathrm{f}_{\mathrm{A}}=5, \mathrm{f}_{\mathrm{B}}=6\right)$ teması altında toplanabileceği anlaşılmıştır. Kiyafet tercihleri $\left(f_{A}=2, f_{B}=1\right)$, gezme tercihleri $\left(f_{A}=2, f_{B}=1\right)$ ve TV'de izlenen programlar $\left(f_{B}=1\right)$ şeklindeki kodlar, seçimlerin değişkenlik göstermesi durumu ile ilgili olduğundan tercihlerin farklı olması $\left(\mathrm{f}_{\mathrm{A}}=4, \mathrm{f}_{\mathrm{B}}=3\right)$ teması altında toplanmıştır. Eve geç gelme $\left(\mathrm{f}_{\mathrm{A}}=1, \mathrm{f}_{\mathrm{B}}=1\right)$ ve ev işlerine yardım etmeme $\left(f_{A}=1\right)$ kodlarının ise içerik olarak yapılması gerekenlerin ihmal 
edilmesiyle ilgili olduğu görülmüş ve bunlar sorumlulukların aksatılması $\left(\mathrm{f}_{\mathrm{A}}=2, \mathrm{f}_{\mathrm{B}}=1\right)$ temasına yerleştirilmiştir.

Yukarıda değinilen temalar içerdikleri frekans sayılarına göre en fazladan en aza doğru sıralandığında; çocuklarla ilgili konular ( $\mathrm{f}=16$ ), olumsuz alışkanlıklar ( $\mathrm{f}=11)$, tercihlerin farklı olması $(\mathrm{f}=7)$ ve sorumlulukların aksatılması $(\mathrm{f}=3)$ şeklinde olduğu görülmektedir. Bu temaları oluşturan her bir koda ilişkin örnekler, katılımcıların ifadelerinden doğrudan alıntılar yapılarak aşağıda sunulmuştur.

\section{Çocuklarla İlgili Konular}

Çocukların eğitimi ile ilgilenmeme: "Çocuklara ders çalıştırma konusunda ben çok titizlenirim o daha rahat bırakır." (A2)

Çocuklara bağırma: “Çocukları uyandırırken çok bağırıyor.” (B10)

Çocukları şımartma: "Ben çocukların dediğini yaptığım zaman, sen bunlara yüz veriyorsun sonra sözümüzü dinlemiyorlar diyor.” (A1)

Çocukları dövme: "Çocuklar konusunda terbiye amaçlı onları dövmek istiyorum. Vurma çocuklara diyor.” (A5)

Çocuklara çok ders çalıştırma: "Çocuklara çok ders çalıştırıyor, biraz serbest bırak çocukları derim. Çocuklar bunalıyor ders çalışmaktan daha beter uzaklaşıyorlar.” (B3)

\section{Olumsuz Alışkanlıklar} (A4)

Savurgan olma: "Para konusunda o çok savurgan, ben paranın tutulmasını istiyorum."

Sigara içme: "Sigara içer o konuda anlaşamıyoruz." (A2)

İnternette fazla zaman geçirme: "Eşim internette çok fazla zaman geçiriyor, onun sürekli internette zaman geçirmesi beni çok rahatsız ediyor.” (B7)

Temiz olmama: "Eşimle temizlik konusunda biraz anlaşamıyoruz, ben onun biraz daha temiz olmasinı istiyorum.” (B6)

İnatlaşma: "Herhangi bir konuda iddia ederiz, ben doğrusu bu derim, yok o benim dediğim dŏgru der." (B1)

\section{Tercihlerin Farklı Olmast}

Kıyafet tercihleri: "Hoşlandığımız şeyler farklıdır özellikle kıyafet konusunda onun

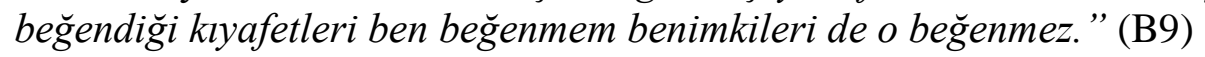

Gezme tercihleri: “Gezmeme çok karışlyor, geziyorsun gelip yatıyorsun diyor.” (B4)

TV'de izlenen programlar: “O dizi izlemek ister ben tartışma programları.” (B10)

\section{Sorumlulukların Aksatılmast}

Eve geç gelme: “Tarlada çok çalışıyor, tarladan eve gelmiyor. Söz dinlemiyor.” (B5)

Ev işlerine yardım etmeme: "Bir işimiz olduğunda bunu yapalım diyorum o anda başka bir şey yapmak istiyorsa benim sözümü dinlemiyor, bana yardım etmiyor.” (A7) 


\subsection{Eşler Arasında Yaşanan Anlaşmazlıklarda Verilen Tepkiler}

Araştırma kapsamında "Yaşadı̆̆ınız bu anlaşmazlıklarda tepkiniz nasıl olur? " sorusuna verilen cevaplara ilişkin elde edilen bulgular frekanslar eşliğinde Tablo 2'de sunulmuştur.

Tablo 2. "Yaşadığınız bu anlaşmazlıklarda tepkiniz nasıl olur?" sorusuna verilen cevaplar doğrultusunda oluşturulmuş kodlar ve temalar

\begin{tabular}{|c|c|c|c|c|}
\hline \multirow{2}{*}{ Tema } & \multirow{2}{*}{ Kodlar } & \multicolumn{3}{|c|}{ Katılıme } \\
\hline & & Anne (f) & Baba (f) & Toplam (f) \\
\hline \multirow{3}{*}{ Saldırganlık Eğilimli Tepkiler } & K1zarım & 4 & 5 & 9 \\
\hline & Bağırırım & 1 & 6 & 7 \\
\hline & Diretirim & & 2 & 2 \\
\hline Toplam & & 5 & 13 & 18 \\
\hline Uzlaşmacı Tepkiler & $\begin{array}{l}\text { Açıklama } \\
\text { yaparım }\end{array}$ & 6 & 8 & 14 \\
\hline Toplam & & 6 & 8 & 14 \\
\hline \multirow{4}{*}{ Kaçınma Tepkileri } & Umursamam & 2 & 2 & 4 \\
\hline & Küserim & 2 & 2 & 4 \\
\hline & Boyun eğerim & 2 & & 2 \\
\hline & A ğlarım & 1 & & 1 \\
\hline Toplam & & 7 & 4 & 11 \\
\hline
\end{tabular}

Tablo 2'de görüldügü üzere katılımcıların verdikleri cevaplara dayalı olarak sekiz farklı kod oluşturulmuştur. Bu kodlar içeriklerine göre üç farklı tema altında toplanmıştır. Oluşturulan kod ve temalara aşağıda ayrıntılarıyla yer verilmiştir.

Katılımcıların, soruya kızarım $\left(f_{A}=4, f_{B}=5\right)$, bağırırım $\left(f_{A}=1, f_{B}=6\right)$ ve diretirim $\left(f_{B}=2\right)$ şeklinde cevaplar verdikleri görülmüştür. $\mathrm{Bu}$ cevaplar karşıdaki kişiye zarar vermek içerikli olduğundan, saldırganlık eğilimli tepkiler $\left(\mathrm{f}_{\mathrm{A}}=5, \mathrm{f}_{\mathrm{B}}=13\right)$ teması altında birleştirilmiştir. Aynı soruya açıklama yaparım gibi bir cevabın verilmesi ise karşıdaki kişiyle anlaşmaya yönelik davranış olması nedeniyle uzlaşmacı tepkiler $\left(\mathrm{f}_{\mathrm{A}}=6, \mathrm{f}_{\mathrm{B}}=8\right)$ teması altına girmesi uygun görülmüştür. Ayrıca bu soruya katılımcıların; umursamam $\left(f_{A}=2, f_{B}=2\right)$, küserim $\left(f_{A}=2, f_{B}=2\right)$, boyun eğerim $\left(\mathrm{f}_{\mathrm{A}}=2\right)$ ve ağlarım $\left(\mathrm{f}_{\mathrm{A}}=1\right)$ şeklinde verdikleri cevaplar problemin çözülmesinin ötelenmesi ile ilgili olmasından dolayı kaçınma tepkileri $\left(\mathrm{f}_{\mathrm{A}}=7, \mathrm{f}_{\mathrm{B}}=4\right)$ teması altında birleştirilmiştir.

Yukarıda değinilen temaların içerdikleri frekans sayılarına göre en fazladan en aza doğru sıralandığında; saldırganlık eğilimli tepkiler $(\mathrm{f}=18)$, uzlaşmacı tepkiler $(\mathrm{f}=14)$ ve kaçınma tepkileri ( $\mathrm{f}=11$ ) şeklinde olduğu görülmektedir. Bu temaları oluşturan her bir koda ilişkin örnekler, katılımcıların ifadelerinden doğrudan alıntılar yapılarak aşağıda sunulmuştur.

\section{Saldırganlık Ĕgilimli Tepkiler}

Kızarım: “Tartıştığımız konularda çoğu zaman öfkeli oluyorum, kızıyorum. ”(A1)

Bağırırım: "Yorgun olduğum zaman sen yap diyorum ve bazen bağırıyorum." (B8)

Diretirim: “Tartıştığımız konularda zorla da olsa en son benim dediğim olur.” (B6)

\section{Uzlaşmacı Tepkiler}

Açıklama yaparım: "Bir şeye hayır dediğimde bunun nedenini açıklarım." (B6) 


\section{Kaçınma Tepkileri}

Umursamam: "Vurdumduymaz davranıyorum mevzuyu geçiştiriyorum.” (B4)

Küserim: "Kırıldığımı belli ederim. Genelde tepkimi küserek belli ederim.” (B6)

Boyun eğerim: "Çok ısrarcı olmam onun dediğini yaparım," (A9)

Ağlarım: "Genelde ağllyorum.” (A7)

\section{2. Çocuklarla Yaşanan Anlaşmazlıklar}

Araştırma kapsamında "Çocuğunuzla hangi konularda anlaşmazlık yaşarsınız?" sorusuna verilen cevaplara ilişkin elde edilen bulgular frekanslar eşliğinde Tablo 3'te sunulmuştur.

Tablo 3. Çocuğunuzla hangi konularda anlaşmazlık yaşarsınız?" sorusuna verilen cevaplar doğrultusunda oluşturulan kodlar ve temalar

\begin{tabular}{|c|c|c|c|c|}
\hline \multirow[b]{2}{*}{ Tema } & \multirow[b]{2}{*}{ Kodlar } & \multicolumn{3}{|c|}{ Katılımcı } \\
\hline & & $\begin{array}{c}\text { Anne } \\
\text { (f) }\end{array}$ & $\begin{array}{c}\text { Baba } \\
\text { (f) }\end{array}$ & $\begin{array}{c}\text { Toplam } \\
\text { (f) }\end{array}$ \\
\hline \multirow{6}{*}{$\begin{array}{l}\text { Sorumlulukların } \\
\text { Aksatılması }\end{array}$} & Ders çalışmaması & 7 & 5 & 12 \\
\hline & Çok televizyon izlemesi & 5 & 1 & 6 \\
\hline & $\begin{array}{l}\text { İnternette fazla zaman } \\
\text { geçirmesi }\end{array}$ & 2 & 2 & 4 \\
\hline & Dağınık olması & 3 & 1 & 4 \\
\hline & D1şarıda çok oynaması & 1 & 1 & 2 \\
\hline & Ev işlerine yardım etmemesi & 2 & & 2 \\
\hline Toplam & & 20 & 10 & 30 \\
\hline \multirow{6}{*}{$\begin{array}{l}\text { Olumsuz Duygusal } \\
\text { Tepkiler }\end{array}$} & Bir şeyi israrla istemesi & 1 & 3 & 4 \\
\hline & Kardeşini kıskanması & 2 & 2 & 4 \\
\hline & Şımarması & 2 & 1 & 3 \\
\hline & Vurdumduymaz olması & & 2 & 2 \\
\hline & Başkalarına özenmesi & 1 & & 1 \\
\hline & Sinirli olması & 1 & & 1 \\
\hline Toplam & & 7 & 8 & 15 \\
\hline \multirow{2}{*}{ Tercihlerin Farklı Olması } & Kiyafet tercihleri & 2 & & 2 \\
\hline & Yemek tercihleri & 1 & & 1 \\
\hline Toplam & & 3 & & 3 \\
\hline
\end{tabular}

Tablo 3’te görüldüğü üzere katılımcıların verdikleri cevaplara dayalı olarak 14 farklı kod belirlenmiştir. Bu kodların üç farklı tema içerisinde yer alabileceği anlaşılmıştır. Belirtilen kodlar ve temalarla ilgili detaylar aşağıda ayrıntılarıyla sunulmuştur.

Katılımcılar bu soruya; ders çalışmaması $\left(f_{A}=7, f_{B}=5\right)$, çok televizyon izlemesi $\left(f_{A}=5\right.$, $\left.f_{B}=1\right)$, internette fazla zaman geçirmesi $\left(f_{A}=2, f_{B}=2\right)$, dağını olması $\left(f_{A}=3, f_{B}=1\right)$, dişarıda çok oynaması $\left(f_{A}=1, f_{B}=1\right)$ ve ev işlerine yardım etmemesi $\left(f_{A}=2\right)$ şeklinde cevaplar vermişlerdir. Bu cevapların bireylerin yerine getirmeleri gereken rolleri gerçekleştirmedikleri ile ilgili olduğu anlaşılmış ve bu cevapların oluşturduğu kodlar, sorumlulukların aksatılması $(\mathrm{f}=30)$ teması 
altında toplanmıştır. Bu soruya verilen diğer cevaplar incelendiğinde; bir şeyi israrla istemesi $\left(f_{A}=1, f_{B}=3\right)$, kardeşini kıskanması $\left(f_{A}=2, f_{B}=2\right)$, şımarması $\left(f_{A}=2, f_{B}=1\right)$, vurdumduymaz olması $\left(f_{B}=2\right)$, başkalarına özenmesi $\left(f_{A}=1\right)$ ve sinirli olması $\left(f_{A}=1\right)$ şeklinde olduğu görülmüştür. Değinilen ifadeler istenmeyen bir takım davranışlar içermesi nedeniyle bu cevaplardan oluşan kodlar olumsuz duygusal tepkiler $(\mathrm{f}=15)$ teması altında toplanmıştır. $\mathrm{Bu}$ soruya ayrıca kıyafet tercihleri $\left(f_{A}=2\right)$ ve yemek tercihleri $\left(f_{A}=1\right)$ cevapları da verilmiş ve bu cevapların oluşturduğu kodlar farklı tercihleri içerdiğinden, tercihlerin farklı olması $(\mathrm{f}=3)$ teması altında birleştirilmiştir.

Yukarıda değinilen temalar, içerdikleri frekans sayılarına göre en fazladan en aza doğru siralandığında; sorumlulukların aksatılması $(\mathrm{f}=30)$, olumsuz duygusal tepkiler $(\mathrm{f}=15)$ ve tercihlerin farklı olması $(\mathrm{f}=3)$ şeklindedir. Bu temaları oluşturan her bir koda ilişkin örnekler, katılımcıların ifadelerinden doğrudan alıntılar yapılarak aşağıda sunulmuştur.

\section{Sorumlulukların Aksatılması}

Ders çalışmamas1: "Dersini çok zor yaptırıyoruz ona. ” (B2)

Çok televizyon izlemesi: “Çok televizyon izliyor, ders yapmıyor.” (A5)

İnternette fazla zaman geçirmesi: "Sürekli internette takıllyor." (B9)

Dağınık olması: “Derli toplu olsun istiyorum ama yok çok dă̆ınık.” (B10)

Dışarıda çok oynaması: "Dışarıda oyun oynuyor, akşam oluyor eve gelmiyor.” (A6)

Ev işlerine yardım etmemesi: "Ben söylemedikçe bana yardım etmez.” (A2)

\section{Olumsuz Duygusal Tepkiler}

Bir şeyi ısrarla istemesi: "Bildiğini okuyor. İstediğinin illa olmasını istiyor” (B8)

Kardeşini kıskanması: “Kardeşiyle oynamıyor onu çok kıskanıyor.” (B6)

Şımarması: "Şımarıklık ediyor, önceden söyledim mi yapardı artık yapmıyor." (A4)

Vurdumduymaz olmas1: “Çok vurdumduymaz bir şey söylediğimde aldırmıyor.” (B5)

Başkalarına özenmesi: "Köyde yaşamak istemiyor, şehirdekilere imreniyor.” (A3)

Sinirli olması: "Ev konusunda dă̆ınık. Abilerine karşı çok sinirli.,” (A1)

\section{Tercihlerin Farklı Olması}

Kıyafet tercihleri: "Klyafet zevkimiz birbirine uymuyor." (B9)

Yemek tercihleri: "Yaptığım yemekleri beğenmiyor çok yemek seçer.” (A5)

\section{1. Çocuklarla Yaşanan Anlaşmazlıklarda Verilen Tepkiler}

Araştırma kapsamında "Yaşadı̆̆ınız bu anlaşmazlıklarda tepkiniz nasıl olur?" sorusuna verilen cevaplara ilişkin elde edilen bulgular frekanslar eşliğinde Tablo 4'te sunulmuştur.

Tablo 4. "Yaşadı̆̆ınız bu anlaşmazlıklarda tepkiniz nasıl olur?" sorusuna verilen cevaplar doğrultusunda oluşturulan kodlar ve temalar

\begin{tabular}{lllll}
\hline \multirow{2}{*}{ Tema } & Kodlar & \multicolumn{3}{c}{ Katılımcı } \\
\cline { 3 - 4 } & & Anne (f) & Baba (f) & $\begin{array}{c}\text { Toplam } \\
\text { (f) }\end{array}$ \\
\hline
\end{tabular}




\begin{tabular}{llccc}
\hline & Bağırırım & 3 & 6 & 9 \\
\cline { 2 - 5 } $\begin{array}{l}\text { Saldırganlık Eğilimli } \\
\text { Tepkiler }\end{array}$ & Kızarım & 6 & 2 & 8 \\
\cline { 2 - 5 } & Ceza veririm & 3 & 3 & 6 \\
\cline { 2 - 5 } & Döverim & 4 & 2 & 6 \\
\cline { 2 - 5 } Toplam & Tehdit ederim & 2 & 2 & 4 \\
\hline \multirow{2}{*}{ Uzlaşmacı Tepkiler } & Açıklama yaparım & $\mathbf{1 8}$ & $\mathbf{1 5}$ & $\mathbf{3 3}$ \\
\cline { 2 - 5 } & Anlaşmaya varırım & 2 & 7 & 10 \\
\hline Toplam & & $\mathbf{5}$ & $\mathbf{7}$ & $\mathbf{1 2}$ \\
\hline
\end{tabular}

Tablo 4'te görüldüğü üzere katılımcıların verdikleri cevaplara dayalı olarak yedi farklı kod belirlenmiştir. Bu kodların iki farklı tema içerisinde yer alabileceği anlaşılmıştır. Belirtilen kodlar ve temalarla ilgili detaylar aşağıda ayrıntılarıyla sunulmuştur.

Katılımcıların bu soruya verdikleri yanıtlarla oluşturulmuş kodlardan bir kısmı; bağırırım $\left(f_{A}=3, f_{B}=6\right)$, kızarım $\left(f_{A}=6, f_{B}=2\right)$, ceza veririm $\left(f_{A}=3, f_{B}=3\right)$, döverim $\left(f_{A}=4, f_{B}=2\right)$ ve tehdit ederim $\left(f_{A}=2, f_{B}=2\right)$ şeklindedir. Bu kodlar karşıdaki kişiye zarar vermek içerikli olduğundan saldırganlık eğilimli tepkiler teması $\left(\mathrm{f}_{\mathrm{A}}=18, \mathrm{f}_{\mathrm{B}}=15\right)$ altında toplanmıştır. Açıklama yaparım $\left(\mathrm{f}_{\mathrm{A}}=3, \mathrm{f}_{\mathrm{B}}=7\right)$ ve anlaşmaya varırım $\left(\mathrm{f}_{\mathrm{A}}=2\right)$ katılımcıların bu soruya verdikleri diğer cevaplardır. Bu cevaplardan oluşan kodlar ise karşıdaki kişiyle anlaşmaya yönelik davranış olması nedeniyle uzlaşmacı tepkiler $\left(\mathrm{f}_{\mathrm{A}}=5, \mathrm{f}_{\mathrm{B}}=7\right)$ teması altında toplanmıştır.

Yukarıda değinilen temalar içerdikleri frekans sayılarına göre en fazladan en aza doğru sıralandığında; saldırganlık eğilimli tepkiler $(\mathrm{f}=33)$ ve uzlaşmacı tepkiler $(\mathrm{f}=12)$ şeklindedir. $\mathrm{Bu}$ temaları oluşturan her bir koda ilişkin örnekler, katılımcıların ifadelerinden doğrudan alıntılar yapılarak aşağıda sunulmuştur.

\section{Saldırganlık Ĕgilimli Tepkiler}

Bağırırım: "Yüksek sesle bă̆ırırım.” (B7)

Kızarım: "Kendimi kontrol edemiyorum, kızlyorum." (A5)

Ceza veririm: "Sözümü dinlemediğinde dışarı çıkmasına izin vermiyorum." (A6)

Döverim: “Arada iki tokat atıyorum ona susar. Gidiyor başka odaya ağllyor.” (B8)

Tehdit ederim: "Ĕ̆ger dediğimi yapmazsan sana istediğini almam diyorum." (A9)

\section{Uzlaşmacı Tepkiler}

Açıklama yaparım: "Mantıklı açıklamalar yaparak ikna etmeye çabalarım" (A7)

Anlaşmaya varırım: "Kalbini kırmadan anlaşmaya çalışırım.” (A3)

\section{B. Çocuklarla Yapılan Görüşmeler Sonucunda Elde Edilen Bulgular}

\section{Anne ve Babayla Yaşanan Anlaşmazlıklar}

Araştırma kapsamında "Anne ve babanızla hangi konularda anlaşmazlık yaşarsınız?" sorusuna verilen cevaplara ilişkin elde edilen bulgular frekanslar eşliğinde Tablo 5'te sunulmuştur.

Tablo 5. "Anne ve babanızla hangi konularda anlaşmazlık yaşarsınız?" sorusuna verilen cevaplar doğrultusunda oluşturulan kodlar ve temalar 


\begin{tabular}{|c|c|c|}
\hline Tema & Kodlar & Çocuk (f) \\
\hline \multirow{9}{*}{ Sorumlulukların Aksatılması } & Derslerimi aksatıyor olmam & 6 \\
\hline & İhtiyaçlarımın karşılanmaması & 5 \\
\hline & TV'de fazla zaman geçirmem & 4 \\
\hline & İnternette fazla zaman geçirmem & 3 \\
\hline & Ev işlerine yardım etmemem & 2 \\
\hline & Temiz olmamam & 2 \\
\hline & Dişarıda uzun süre oynamam & 1 \\
\hline & Annemin sözünü dinlememem & 1 \\
\hline & Yatma saatini geciktirmem & 1 \\
\hline Toplam & & 25 \\
\hline \multirow{2}{*}{ Baskı Kurulması } & Kendi dediğini yaptırması & 2 \\
\hline & Ev işi yaptırması & 2 \\
\hline Toplam & & 4 \\
\hline \multirow{3}{*}{ Tercihlerin Farklı Olması } & TV'de izlediğim programlar & 1 \\
\hline & Arkadaş tercihlerim & 1 \\
\hline & Yemek tercihlerim & 1 \\
\hline Toplam & & 3 \\
\hline
\end{tabular}

Tablo 5'te görüldüğü üzere katılımcıların verdikleri cevaplara dayalı olarak 14 farklı kod belirlenmiştir. Bu kodların üç farklı tema içerisinde yer alabileceği anlaşılmıştır. Belirtilen kodlar ve temalarla ilgili detaylar aşağıda ayrıntılarıyla sunulmuştur.

Çocukların bu soruya verdikleri cevaplarla oluşturulmuş kodlar, derslerimi aksatıyor olmam ( $\mathrm{f}=6)$, ihtiyaçlarımın karşılanmaması $(\mathrm{f}=5)$, TV'de fazla zaman geçirmem $(\mathrm{f}=4)$, internette fazla zaman geçirmem $(\mathrm{f}=3)$, ev işlerine yardım etmemem $(\mathrm{f}=2)$, temiz olmamam $(\mathrm{f}=2)$, dışarıda uzun süre oynamam ( $\mathrm{f}=1$ ), annemin sözünü dinlememem ( $\mathrm{f}=1$ ) ve yatma saatini geciktirmem ( $\mathrm{f}=1)$ şeklindedir. Bu kodların içeriği incelendiğinde bireylerin yerine getirmeleri gereken görevleri gerçekleştirmedikleri ile ilgili olduğu anlaşılmış ve bu cevapların oluşturduğu kodlar, sorumlulukların aksatılması $(\mathrm{f}=25)$ teması altında toplanmıştır. Kendi dediğini yaptırması ( $\mathrm{f}=2$ ) ve ev işi yaptırması $(\mathrm{f}=2)$ bu soruya verilmiş katılımcı cevaplarıyla oluşturulmuş diğer kodlardır. Bu kodların, karşıdaki kişinin istemediği şeylerin yaptırılması ile ilgili olduğu anlaşılmış ve baskı kurulması $(\mathrm{f}=4)$ teması altına yerleştirilmesi uygun görülmüştür. Aynı soruya çocukların verdikleri diğer cevaplarla oluşturulmuş kodlar ise; TV'de izlediğim programlar $(\mathrm{f}=1)$, arkadaş tercihlerim $(\mathrm{f}=1)$ ve yemek tercihlerim $(\mathrm{f}=1)$ şeklindedir. $\mathrm{Bu}$ cevapların oluşturduğu kodların farklı tercihleri içerdiğinden, tercihlerin farklı olması $(\mathrm{f}=3)$ teması altında toplanmasına karar verilmiştir.

Yukarıda değinilen temalar içerdikleri frekans sayılarına göre en fazladan en aza doğru sıralandığında; sorumlulukların aksatılması $(\mathrm{f}=25)$, bask kurulması $(\mathrm{f}=4)$ ve tercihlerin farklı olması $(\mathrm{f}=3)$ şeklindedir. Bu temaları oluşturan her bir koda ilişkin örnekler, katılımcıların ifadelerinden doğrudan alıntılar yapılarak aşağıda sunulmuştur.

\section{Sorumlulukların Aksatılmast}

Derslerimi aksatıyor olmam: "Geç olmadan ödevlerini yap diyor. Ben bir şey istediğimde yapmiyor. " (Ç10)

İhtiyaçlarımın karşılanmaması: "Bir gün demiştim ona ihtiyaçlarımı al diye unuttu diye tartıştık. Başka günlerde de oluyor öyle şeyler.” (Ç6) 
TV de fazla zaman geçirmem: "Bazen çok TV izliyorum babam TV izleme artık ödevlerini yap diyor." (Ç8)

İnternette fazla zaman geçirmem: "Uzun süre internette zaman geçirirsem kızar.” (Ç7)

Ev işlerine yardım etmemem: "Ev işlerinde yardım etmiyorum ve tartışlyoruz." (Ç5)

Temiz olmamam: "Bazen elbiselerimi terli dolaba atıyorum annem de kızıyor" (Ç1)

Dışarıda uzun süre oynamam: "Dlşarıda çok oynarsam eve gel diyor.” (Ç7)

Annemin sözünü dinlememem: "Annemin söylediklerini yapmadiğımda babam bana kızıyor." (Ç2)

Yatma saatini geciktirmem: "Yatma saatleriyle ilgili, bir saat belirliyor. Ben de erken yatmak istemiyorum." (Ç9)

\section{Baskı Kurulması}

Kendi dediğini yaptırması: “Kendi dediklerini yapmayınca babam da kızıyor.” (Ç2)

Ev işi yaptırması: "Bazen ev işlerinde yardım etmiyorum, bundan tartışıyoruz. ” (Ç5)

\section{Tercihlerin Farklı Olmast}

TV'de izlediğim programlar: "Benim istediğim filmi aç diyor ben de bazen açmıyorum tartışlyoruz." (Ç6)

Arkadaş tercihlerim: "Sevmedikleri kişilerle oynamama izin vermiyor." (Ç1)

Yemek tercihlerim: "Yemek seçerim o da aynı yemekleri yapıyor anlaşamıyoruz" (Ç9)

\subsection{Anne ve Babayla Yaşanan Anlaşmazlıklarda Verilen Tepkiler}

Araştırma kapsamında "Yaşadı̆̆ınız bu anlaşmazlıklarda tepkiniz nasıl olur? ” sorusuna verilen cevaplara ilişkin elde edilen bulgular frekanslar eşliğinde Tablo 6' da sunulmuştur. 
Tablo 6. "Yaşadığınız bu anlaşmazlıklarda tepkiniz nasıl olur?" sorusuna verilen cevaplar doğrultusunda oluşturulan kodlar ve temalar

\begin{tabular}{lll}
\hline Tema & Kodlar & Çocuk (f) \\
\hline \multirow{2}{*}{ Saldırganlık Eğilimli Tepkiler } & Kizma & 8 \\
\cline { 2 - 3 } & Bağırma & 6 \\
\hline Toplam & & $\mathbf{1 4}$ \\
\hline \multirow{4}{*}{ Kaçınma Tepkileri } & Umursamama & 3 \\
\cline { 2 - 3 } & A ğlama & 3 \\
\cline { 2 - 3 } & Ortamdan uzaklaşma & 2 \\
\cline { 2 - 3 } & Küsme & 2 \\
\cline { 2 - 3 } Toplam & Tepki vermeme & 2 \\
\hline \multirow{3}{*}{ Uzlaşmacı Tepkiler } & & $\mathbf{1 2}$ \\
\hline Toplam & Açılama yapma & 5 \\
\cline { 2 - 3 } & Anlaşmaya varma & $\mathbf{9}$ \\
\cline { 2 - 3 } & Rica etme & \\
\hline
\end{tabular}

Tablo 6'da görüldüğü üzere katılımcıların verdikleri cevaplara dayalı olarak 10 farklı kod belirlenmiştir. Bu kodların üç farklı tema içerisinde yer alabileceği anlaşılmıştır. Belirtilen kodlar ve temalarla ilgili detaylar aşağıda ayrıntılarıyla sunulmuştur.

Çocukların bu soruya verdikleri cevaplar doğrultusunda oluşturulan kodlar; kızma ( $\mathrm{f}=8)$ ve bağırma $(\mathrm{f}=6)$ şeklindedir. Bu kodlar karşıdaki kişiye zarar vermek içerikli olduğundan saldırganlık eğilimli tepkiler teması $(\mathrm{f}=14)$ altında toplanmıştır. Aynı zamanda bu soruya katılımcıların verdikleri cevaplar incelenerek; umursamama $(\mathrm{f}=3)$, ağlama $(\mathrm{f}=3)$, ortamdan uzaklaşma $(\mathrm{f}=2)$, küsme $(\mathrm{f}=2)$ ve tepki vermeme $(\mathrm{f}=2)$ kodları oluşturulmuştur. Bu kodlar problemin çözülmesinin ötelenmesi ile ilgili olmasından dolayı kaçınma tepkileri $(\mathrm{f}=12)$ teması altında toplanmıştır. Açıklama yapma $(\mathrm{f}=5)$, anlaşmaya varma $(\mathrm{f}=3)$ ve rica etme $(\mathrm{f}=1)$ ise katılımcı cevaplarıyla oluşturulmuş diğer kodlardır. Bu kodlar karşıdaki kişiyle anlaşmaya yönelik davranışlar olması nedeniyle uzlaşmacı tepkiler $(\mathrm{f}=9)$ teması altında toplanmıştır.

Yukarıda değinilen temalar içerdikleri frekans sayılarına göre en fazladan en aza doğru sıralandiğında; saldırganlık ĕgilimli tepkiler $(\mathrm{f}=14)$, kaçınma tepkileri $(\mathrm{f}=12)$ ve uzlaşmacı tepkiler $(\mathrm{f}=9)$ şeklindedir. Bu temaları oluşturan her bir koda ilişkin örnekler, katılımcıların ifadelerinden doğrudan alıntılar yapılarak aşağıda sunulmuştur.

\section{Saldırganlık Ĕğilimli Tepkiler}

Kızma: “Annem eve gel dediğinde biraz daha oynayayım diyorum ve klzıyorum.” (Ç1)

Bağırma: “Bazen bağırıyorum. Bazen ona bir şey demeden dışarı çıkıyorum.” (Ç5)

\section{Kaçınma Tepkileri}

Umursamama: "Hoşuma giderse dediğini yaparım, sinirliysem dinlemem bile.” (Ç9)

Ağlama: “Bazen biraz darılırım, odanın bir kenarına giderim ağlarım. ” (Ç2)

Ortamdan uzaklaşma: "Anneme bir şey söylemiyorum etrafı topluyorum. Bazen de evden çıkıyorum." (Ç2)

Küsme: “Mutsuz oluyorum birazcık, küsüyorum.” (Ç4)

Tepki vermeme: “Beni kızdırdığında onu muhatap almıyorum.” (Ç9) 


\section{Uzlaşmacı Tepkiler}

Açıklama yapma: "Annem babama sigarayı bırak artık dediğinde, babam merak etme ben de bırakmayı çok istiyorum yakın zamanda bırakacağım diyor.” (Ç3)

Anlaşmaya varma: "Bazı konularda babama diyor ki çocuk istediğini yapsın. Bazen de babanın sözünü dinle, dediğini yap diyor.” (Ç10)

Rica etme: "Çoğu zaman lütfen diye rica ediyorum." (Ç10)

\section{TARTIŞMA, SONUÇ VE ÖNERİLER}

$\mathrm{Bu}$ araştırmada temel olarak aile içinde yaşanan anlaşmazlıklar ve bu anlaşmazlıklarda ortaya koyulan tepkiler doğrudan anne, baba ve çocukların görüşleri incelenerek belirlenmeye çalışılmıştır. Bu amaç doğrultusunda aile içerisinde eşler arasında, anne-baba ve çocuk arasında hangi konularda anlaşmazlıklar yaşandığı ve yaşanan bu anlaşmazlıklarda aile üyelerinin nasıl tepkiler verdikleri incelenmiştir. Bu bölümde değinilen amaç ve alt amaçlar ile ilgili ulaşılan sonuçlar ilgili literatür ışığında tartışılmış ve yorumlanmıştır.

Araştırmada elde edilen sonuçlardan birisi eşlerin en çok çocuklarla ilgili konularda, bunun yanında olumsuz alışkanlıklar, tercihlerin farklı olması ve sorumlulukların aksatılması konularında anlaşmazlık yaşadıklarıdır. Bu sonucu destekler nitelikte evlilik çatışması üzerine yapılan araştırmalarda anlaşmazlığın çoğunlukla çocuk yetiştirme konusunda ortaya çıktığına dikkat çekilmektedir (Cummings ve Davies, 2014; Papp, Commings ve Goeke-Morey, 2009). Türk aile yapısına ilişkin gerçekleştirilen bir araştırmada ise evli bireylerin eşleriyle daha çok sırasıyla; ev ile ilgili sorumluluklar, çocuklar ile ilgili sorumluluklar, ailece birlikte zaman geçirmeme, harcamalar, giyim tarzı, ailesi ile ilişkiler, alkol alışkanlığı, sigara alışkanlığı, işi ile ilgili sorunların eve taşınması, gelirinin yeterli olmaması, arkadaşlar, görüşülen kişiler, kendine yeterince özen göstermeme, internet, kıskançlık, kişilik farklılıkları ve eğlence alışkanlıkları konularında anlaşmazlıklar yaşadıkları tespit edilmiştir (TÜİK, 2016). Değinilen bu sonuçlar ile araştırmadan elde edilen sonuçların benzerlik gösterdiği anlaşılmaktadır. Çocukların sağlıklı kişilik gelişiminde anne-babanın çocuğa karşı tutum ve davranışlarında tutarlı ve kararlı davranmaları önemli bir etkiye sahiptir (Semerci, 2012). Ancak eşlerin her birinin kendi kök ailelerinin etkisinde gelişen farklı iletişim tarzları nedeniyle çocuklara yönelik tutum ve davranışlarında ortak bir tavır geliştirmeleri çoğu zaman mümkün olamamaktadır (Aydın, 2013). Bu nedenle çocuklara nasıl davranılması ve ne tür sınırlar koyulması gerektiğiyle ilgili eşler arasında sık sık çatışmalar yaşanmaktadır. Bu durum ise araştırmada ulaşıldığı üzere eşler arasında anlaşmazlık yaşanan bir duruma dönüşebilmektedir. Benzer şekilde eşlerin alışageldiği olumsuz alışkanlıklarını sürdürmeleri, eşlerinden farklı olan tercihlerinde 1srarcı olmaları ve aile içerisinde yerine getirmeleri gereken görevleri ihmal etmelerinin aile içerisinde anlaşmazlıklar yaşamalarına yol açtığı anlaşılmaktadır. Bu sonuçlar bağlamında tarafların olumlu yönde değişime açık olmalarının ve bu yönde çaba sarf etmelerinin yaşanabilecek anlaşmazlıkları azaltacağı değerlendirilmektedir.

Araştırmada anne-babaların çocuklarıyla en çok çocuklarının sorumluluklarını aksatmaları, bunun yanında çocuklarının sergiledikleri olumsuz duygusal tepkiler ve tercihlerinin farklı olmasından ötürü anlaşmazlık yaşadıkları sonucuna ulaşılmıştır. Bu durum çocuklara sorulduğunda ise anne-babalarıyla daha çok sorumluluklarını yerine getirmedikleri için ayrıca kendilerine baskı kurulması ve tercihlerinin farklı olmasından kaynaklı olarak anlaşmazlık yaşadıklarını ifade ettikleri görülmüştür. Dolayısıyla anne-babaların çocuklarıyla yaşadıkları anlaşmazlıklar ile çocukların anne-babalarıyla yaşadıkları anlaşmazlıklar arasında bir tutarlılık olduğu anlaşılmaktadır. Bu konuda yapılan araştırmalarda çocuklar, diğer sosyal ilişkilerine oranla aileleriyle daha fazla anlaşmazlık yaşadıklarını belirtmişlerdir (Kaya ve Tuna, 2010; Laursen, 1995). Twenge ve Campbell (2010) bu konuda otoriteyi çocuklarına 
bırakan, onlara hak etmedikleri övgülerde bulunan ve özgürlük tanırken beraberinde sorumluluk vermeyen anne-babaların giderek daha sık göründüğüne dikkat çekmektedir. Değinilen bu ve benzeri durumlar nedeniyle ebeveyn ile çocuk arasındaki ilişkinin sağlığının zarar gördüğü ve bunun sonucunda çatışmaların kaçınılmaz olduğu düşünülmektedir. Ebeveyn tutumları ile ilgili olarak Baumrind (1971) otoriter, demokratik ve hoşgörülü olmak üzere üç tip anne-baba tutumunun olduğuna değinmiştir. Otoriter ebeveynler katı ve değişmez kurallar koyma eğilimindedir ve bu tür ebeveynler koyulan kurallara çocuğun sorgulamaksızın uymasını bekler. Bu tür ebeveynlerin çocuklarının iletişim becerisi zayıftır ve sosyal açıdan yetersizlikler yaşarlar. Demokratik ebeveynlerin davranışları birbiriyle tutarlı, kararlı ve güven vericidir. Çocukların özerkliğine zarar verilmeden kontrol sağlanır ve çocukların ihtiyaçlarının karşılanmasında duyarlılık gösterilir. Bu tür ailelerde çocuklar genellikle neşeli, öz denetim sahibi, kendine güvenli ve başarı yönelimlidir. Hoşgörülü ebeveynler çocuklarıyla yakından ilgilenmekte ancak çocuğa sınır koyma ve kontrol etme konusunda yetersiz kalmaktadırlar. Bu tür ailelerde yetişen çocukların duygu ve davranışlarını kontrol etmede zorlandıkları, stresle başa çıkma ve sorumluluk alma gibi konularda sorunlar yaşadıkları gözlenmiştir (Maccoby ve Martin, 1983; Santrock, 2012). Bu bilgiler 1şı̆̆ında ebeveynlerin demokratik tutumlarını geliştirmelerinin çocuklarının sorumluluk alma davranışlarını olumlu yönde etkileyeceği ve çocuklarıyla yaşayacakları anlaşmazlıkları azaltacağı düşünülmektedir.

Çocukların hangi konularda sorumluluklarını aksattıkları incelendiğinde ise çoğunlukla ders çalışmanın ihmal edilmesi, çok televizyon izlenmesi ve internette fazla zaman geçirilmesi gibi durumların olduğu anlaşılmıştır. Son yıllarda yapılan araştırmalarda çocukların internet, sosyal medya kullanımı ve mesajlaşmalarında artış olduğu ortaya koyulmaktadır (Demir, 2016; Kırık, Arslan, Çetinkaya ve Gül, 2015; Lenhart, Purcell, Smith ve Zickuhr, 2010). Demir'in (2016) yaptığı araştırmada; sosyal medyayı kullanım süresi yoğun olan öğrencilerin problemlerini aileleri yerine sosyal medyadaki arkadaşlarıyla paylaşmayı tercih ettikleri, aile içinde konuşulan konulardan sıkıldıkları ve aileleri ile beraberken bile sosyal medyada olan olayları merak ettikleri tespit edilmiştir. Bu bağlamda çocukların interneti ve mobil teknolojiyi kontrolsüz bir şekilde kullanarak zamanlarının çoğunu sanal dünyada geçirmelerinin aile içi ilişkilerini olumsuz yönde etkilediği anlaşılmaktadır. Dolayısıyla bu durum ebeveynler ile çocukları arasında bir anlaşmazlığa dönüşmektedir. Ayrıca eşlerin kendi aralarında ve anne ve babaların çocuklarıyla yaşadıkları anlaşmazlıkların nedenlerinden birisi de tercihlerin farklı olması olarak belirlenmiştir. Anne-babalar hem kendi aralarında hem de çocuklarıyla kıyafet, yemek, TV'de izlenen program, arkadaş ve gezme tercihleri konularında anlaşmazlık yaşadıklarını belirtmişlerdir. Modern yaşamla birlikte makro düzeyde neoliberal politikaların ve popüler kültürün de etkisiyle seçeneklerin artması, tercihlerin hem farklılaşmasına hem de zorlaşmasına sebep olmuştur. Bazı araştırmalar özellikle popüler kültürün çocukların aile ilişkileri üzerinde olumsuz etki yaptığına dikkat çekmektedir (Kaya ve Tuna, 2010). Solmaz ve arkadaşlarının (2013) yaptıkları bir araştırmada katılımcılar herhangi bir markayı satın alma davranışı sergilerken sosyal medyadan büyük oranda etkilendiklerini belirtmişlerdir. $\mathrm{Bu}$ bağlamda insanların tercihleri üzerinde popüler kültürün oldukça etkili olduğu kabul edilmektedir (Özgan, Arslan ve Kara, 2014). Aile bireylerinin tercihte bulunurken beraber hareket etmemesi ve ortak kararlar alamamaları ise taraflar arasında anlaşmazlığa neden olan bir durum ortaya çıkarmaktadır. Bununla birlikte aile içerisinde demokratik bir anlayışın hâkim olması ile bir kişinin aldığı karara diğerlerinin saygı duymasının yaşanabilecek birçok anlaşmazlığı önleyeceği düşünülmektedir.

Aile içinde yaşanan anlaşmazlıklara verilen tepkiler konusundaki sonuçlar değerlendirildiğinde; eşlerin aralarındaki anlaşmazlıklara daha çok saldırganlık eğilimli tepkiler, bunun yanında uzlaşmacı ve kaçınmacı tepkiler verdikleri görülmüştür. Anne-babalar çocuklarıyla yaşadıkları anlaşmazlıklarda da uzlaşmacı tepkilerden daha çok saldırganlık 
eğilimli tepkiler ortaya koymuşlardır. Çocuk katılımcılar da benzer şekilde anne ve babalarıyla yaşadıkları anlaşmazlıklarda daha çok saldırganlık eğilimli tepkiler, bunun yanında kaçınmacı ve uzlaşmacı tepkiler geliştirdiklerini ifade etmişlerdir. Eşlerin kendi aralarında ve anne ve babaların çocuklarıyla yaşadıkları anlaşmazlıkları daha çok saldırgan eğilimli davranışlarla çözmeye çalışmaları, çatışma yönetimi ve iletişim becerileri konularında yeterli bilgi ve deneyime sahip olmadıklarını ve çocuklarına olumsuz rol model olduklarını göstermektedir. Saldırgan tavırlar sergileyen uyumsuz çocukların aile ilişkileri incelendiğinde, bu çocukların anne-babalarının disiplin yöntemi olarak fiziksel cezalandırmayı sık kullandıkları tespit edilmiştir (Becker, 1993). Benzer şekilde Jenkins (2000) yaptığı araştırmada eşler arasında yaşanan çatışmalarda sergilenen öfkenin çocukların saldırganlığını da arttırdığı sonucuna ulaşmıştır. Sezer ve arkadaşları (2013) ise yaptıkları araştırmada; çocukların saldırganlık düzeylerinin anne-baba tutumlarından etkilendiğini vurgulamışlardır. Taylor, Peplau ve Sears (2007: 414) saldırganlığın nedenlerinden birisinin de taklit olduğunu ifade etmişlerdir. Çocukların sık gördüğü kişileri daha fazla taklit ettiği bu noktada ebeveynlerin önemli bir belirleyici olduğuna değinmişlerdir. Ayrıca çocukların saldırgan davranışlarında ebeveynlerin çocuklarına ve birbirlerine nasıl davrandıklarının etkili olduğuna vurgu yapmışlardır. $\mathrm{Bu}$ açıklamalar ışığında araştırmadan elde edilen sonuçlar ebeveynlerin çocukların için etkili birer model olmaları ile açıklanabilir. Ayrıca yapılan araştırmalara göre; aile içinde yaşanan anlaşmazlıkların ya da çatışmaların yönetiminde etkili iletişim becerilerinin kullanılması hem evlilik ilişkisinin sağlıklı gelişimi açısından, hem de çocuklara olumlu rol model olma açısından son derece önemlidir (Balc1 ve Yılmaz, 2000; Şahin ve Aral, 2012; Thomas, 1976). Nitekim araştırmalar evlilik doyumunun iyi bir ebeveynlikle ilişkili olduğunu ortaya koymakta ve mutlu bir evliliği olan ebeveynlerin çocuklarına karşı daha duyarlı, ilgili, samimi ve şefkatli olduğunu göstermektedir (Carlson, Pilkauskas, McLanahan ve Brooks-Gunn, 2011). Dolayısıyla eşlerin kendi aralarında yaşadıkları anlaşmazlıklarda ortaya koydukları tepkilerin doğrudan ya da dolaylı şekilde çocuklarını da etkilediği ve bu durumun ise ailedeki tüm bireylerin benzer olumsuz davranışlar sergilemelerine neden olduğu anlaşılmaktadır.

Aile içinde anne-baba ve çocuklar arasındaki anlaşmazlıkların incelendiği bu çalışmanın sonuçlarına göre; toplumun en küçük sosyal birimi olan ailede; çocuklarla ilgili konular, olumsuz alışkanlıklar, tercihlerin farklı olması ve sorumlulukların aksatılması durumlarında anlaşmazlıklar yaşandığı anlaşılmıştır. Aile içinde yaşanan bu anlaşmazlıklar karşısında ise aile bireylerinin uzlaşmacı tepkiler yerine, daha çok saldırganlık ve kaçınmacı tepkiler ortaya koydukları görülmüştür. Aile üyeleri arasında dış dünyadan etkilenen dinamik bir iletişim ve etkileşim süreci işlemektedir. Bu etkileşim sürecinde eşlerin kendi aralarında ve çocuklarıyla olan iletişimlerinde doğal olarak bir takım anlaşmazlıklar ortaya çıkmaktadır. Araştırmanın sonuçlarına göre; aile içinde yaşanan anlaşmazlıkların çözümünde ya da yönetilmesinde aile üyelerinin etkili iletişim becerilerini yeterli düzeyde kullanamadıkları anlaşılmıştır. Dolayısıyla anne, baba ve çocuklara yönelik olarak öfke, saldırganlık, problem çözme ve çatışma yönetimi gibi konularda psiko-eğitim programları ve psikolojik danışma oturumlarının düzenlenmesi gerekmektedir. Araştırma sonucunda eşlerin birbirlerine yönelik davranışlarının çocuklarının davranışlarına da yansıdığı anlaşılmıştır. Bu nedenle evliliği güçlendirme programlarının yaygınlaştırılmasının aile bireylerinin tümümün ruh sağlı̆̆ açısından önemli katkılar sağlayacağı düşünülmektedir. Bu noktadan hareketle modern kent yaşamında geleneksel destek unsurlarından yoksun kalan ailelerin yaşadıkları sorunlarla ilgili profesyonel danışmanlık hizmeti alacakları kurumlara ihtiyaç duydukları düşünülmektedir. $\mathrm{Bu}$ konuda önemli bir boşluğu dolduracağı düşünülen aile danışmanlığı uygulaması ülke genelinde istenilen düzeyde yaygınlaşmamıştır. Aile danışmanlığı uygulamalarının sosyo-ekonomik ve sosyo-kültürel düzeyine bakılmaksızın her aile için ulaşılabilirliğinin artmasının bireylerin aile yaşantılarına olumlu yönde katkı sağlayacağı değerlendirilmektedir. Bu çalışmanın nitel araştırmanın yaklaşımına dayalı olarak yapılması, 30 kişiden oluşan bir çalışma grubu ile 
gerçekleştirilmesi ve araştırmacılar tarafından geliştirilen yarı yapılandırılmış görüşme formları kullanılarak elde edilen verilerden sonuçlara ulaşması noktalarında genellebilirlik açısından sınırlıklara sahiptir. Bu durumla ilgili olarak, aile içinde yaşanan anlaşmazlıklar, nicel araştırma yaklaşımına dayalı, daha fazla katılımcının yer aldığı ve ilişkili olduğu düşünülen değişkenlerin de dikkate alındığı araştırmalarla daha ayrıntılı şekilde incelenebilir.

\section{KAYNAKÇA}

ASPB. (2015). Türkiye Boşanma Nedenleri Araştırması-2014. İstanbul: Çizge Tanıtım.

Aydın, B. (2013). Çocuk ve Ergen Psikolojisi (4. b.). Ankara: Nobel Akademik Yayıncılık.

Ayçiceçeği Dinn, A., \& Caldwell-Harris, C. L. (2016). How collectivism and family control influence depresslve symptoms in Asian American and European American college students. Elektronik Sosyal Bilimler Dergisi (www.esosder.org). 15(57), 579-599.

Babahanoğlu, R., \& Özdemir, S. G. (2016). Aile İçi Şiddetin Çocuk Üzerindeki Etkisi Konusunda Sosyal Hizmet ve Hukuk Fakültesi Öğrencilerinin Görüşlerinin İncelenmesi. Hitit Üniversitesi Sosyal Bilimler Enstitüsü Dergisi, 9(2), 1067-1087.

Balcı, S., \& Yılmaz, M. (2000). Çocukları Anaokuluna Devam Eden Annelere Verilen İletişim Becerileri Eğitiminin Ailenin İşlevlerine Etkisi. Türk Psikolojik Danışma ve Rehberlik Dergisi, 2(14), 17-24.

Başoğul, C., Lök, N., \& Öncel, S. (2017). Çocukların Aile İçi Şiddetten Korunmasında Ailelere Yönelik Girişimler. Psikiyatride Güncel Yaklaşımlar, 9(2), 123-135.

Baumrind, D. (1971). Current Patterns of Parental Authority. Devolopmental Psychology Monograps, 4(2), 1-103.

Becker, G. S. (1993). A Treatise on the Family. Cambridge: Harvard University Press.

Berg, B. L., \& Lune, H. (2015). Sosyal Bilimlerde Nitel Araştırma Yöntemleri. Konya: Eğitim Yayinevi.

Carlson, M. J., Pilkauskas, N. V., McLanahan, S. S., \& Brooks-Gunn, J. (2011). Couples as Partners and Parents Over Children's Early Years. Journal of Marriage and Family, 73(2), 317-334.

Creswell, J. W. (2013). Nitel Araştırma Yöntemleri. (M. Bütün, \& S. B. Demir, Çev.) Ankara: Siyasal Kitabevi.

Cummings, E. M., \& Davies, P. T. (2002). Effects of Marital Conflict on Children: Recent Advances and Emerging Themes in Process-Oriented Research. Journal of Child Psychology and Psychiatry, 43(1), 31-63.

Cummings, E. M., \& Davies, P. T. (2014). Çocuklar ve Evlilik Çatışması: Aile Anlaşmazlı̆̆g ve Çözümünün Etkisi. (G. Şendil, Çev.) Ankara: Nobel Akademik Yayıncılık.

Çağ, P., \& Yıldırım, İ. (2013). Evlilik Doyumunu Yordayan İlişkisel ve Kişisel Değişkenler. Türk Psikolojik Danışma ve Rehberlik Dergisi, 4(39), 13-23.

Demir, Ü. (2016). Sosyal Medya Kullanımı ve Aile İletişimi: Çanakkale'de Lise Öğrencileri Üzerine Bir Araştırma. Selçuk Iletişim, 9(2), 27-50.

Demirtaş-Zorbaz, S., \& Korkut-Owen, F. (2013). Çocuklar İçin Aile İlişkileri Ölçeği'nin Geliştirilmesi. Türk Psikolojik Danışma ve Rehberlik Dergisi, 4(39), 58-67. 
El-Sheikh, M., Buckhalt, J. A., Mark Cummings, E., \& Keller, P. (2007). Sleep disruptions and emotional insecurity are pathways of risk for children. Journal of Child Psychology and Psychiatry, 48(1), 88-96.

Güven, E., \& Erden, G. (2014). Çocuğun Algıladığı Evlilik Çatışması ve Davranış Sorunları. Sosyal Politika Çalışmaları Dergisi, 14(32), 33-54.

Hortaçsu, N. (2015). Zamanda Aile Ailede Zaman. Ankara: İmge Kitabevi Yayınları.

Jenkins, J. M. (2000). Marital conflict and children's emotions: The development of an anger organization. Journal of Marriage and Family, 62(3), 723-736.

Kaner, S., \& Bayraklı, H. (2010). Aile Yılmazlık Ölçeği: Geliştirilmesi, Geçerliği ve Güvenirliği. Ankara Üniversitesi Eğitim Bilimleri Fakültesi Özel Ĕ̆itim Dergisi, 11(2), 47-62.

Kaya, K., \& Tuna, M. (2010). Popüler Kültürün İlköğretim Çağındaki Çocukların Aile İçi İlişkileri Üzerindeki Etkisi. SDÜ Fen Edebiyat Fakültesi Sosyal Bilimler Dergisi(21), 237-256.

Keçeli-Kaysılı, B. (2008). Akademik Başarının Arttırılmasında Aile Katılımı. Ankara Üniversitesi Ĕgitim Bilimleri Fakültesi Özel Eğitim Dergisi, 9(1), 69-83.

Kırık, A. M., Arslan, A., Çetinkaya, A., \& Gül, M. (2015). A Quantitative Research on the Level of Social Media Addiction among Young People in Turkey. International Journal of Science Culture and Sport, 3(3), 108-122.

Kocayörük, E. (2010). Ergen Gelişiminde Aile İşlevleri ve Baba Katılımı. Türk Psikolojik Danışma ve Rehberlik Dergisi, 4(33), 37-45.

Krishnakumar, A., \& Buehler, C. (2000). Conflict and Parenting Behaviors: A Meta-Analytic Review. Family Relations, 49(1), 25-44.

Laursen, B. (1995). Conflict and Social Interaction in Adolescent Relationships. Journal of Research on Adolescence, 5(1), 55-70.

Lenhart, A., Purcell, K., Smith, A., \& Zickuhr, K. (2010). Social Media and Young Adults. Washington D.C.: Pew Research Center.

Maccoby, E. E., \& Martin, J. A. (1983). Socialization in the Context of the Family: ParentChild Interaction. P. H. Mussen, \& E. M. Hetherington içinde, Handbook of Child Psychology: Socialization, Personality and Social Development (s. 1-101). New York: Wiley.

Manning, K. (1997). Authenticity in Constructivist Inquiry: Methodological Considerations Without Prescription. Qualitative Inquiry,, 3(1), 93-115.

Mavili, A., Kesen, N. F., \& Daşbaş, S. (2014). Aile Aidiyeti Ölçeği: Bir Ölçek Geliştirme Çalışması. Sosyal Politika çalışmaları Dergisi, 14(33), 29-45.

McCoy, K. P., George, M. R., Cummings, E. M., \& Davies, P. T. (2013). Constructive and Destructive Marital Conflict, Parenting, and Children's School and Social Adjustment. Social Development, 22(4), 641-662.

Miles, M. B., \& Huberman, A. M. (1994). Qualitative Data Analysis: An Expanded Sourcebook. California: Sage Publications.

Nazlı, S. (2001). Aile Danışmanlı̆̆̆. Ankara: Nobel Yayın Dağıtım. 
Olson, D. H., Sprenkle, D. H., \& Russell, C. S. (1979). Circumplex Model of Marital and Family Systems: I. Cohesion and Adaptability Dimensions, Family Types, and Clinical Applications. Family Process, 18(1), 3-28.

Özer, A., \& Cihan-Güngör, H. (2012). Yükleme Tarzları, Bağlanma Stilleri ve Kişilik Özelliklerine Göre Evlilik Uyumu. Mersin Üniversitesi Ĕ̆itim Fakültesi Dergisi, 8(2), $11-24$.

Özgan, H., Arslan, M. C., \& Kara, M. (2014). Popüler Kültürün Öğrenci Davranışları Üzerinde Algılanan Etkileri. EKEV Akademi Dergisi, 18(58), 469-484.

Papp, L. M., Cummings, E. M., \& Goeke-Morey, M. C. (2009). For richer, for poorer: Money as a topic of marital conflict in the home. Family relations, 58(1), 91-103.

Sak, R., Şahin-Sak, İ. T., Atli, S., \& Şahin, B. K. (2015). Okul Öncesi Dönem: Anne Baba Tutumları. Mersin Üniversitesi Ĕgitim Fakültesi Dergisi, 11(3), 972-991.

Santrock, J. W. (2012). Yaşam Boyu Gelişim: Gelişim Psikolojisi. Ankara: Nobel Akademik Yayıncilik.

Semerci, Z. B. (2012). Birlikte Büyütelim: Çocuk Ruh Să̆lı̆̆l (7. b.). İstanbul: Alfa Basım Yayim.

Sezer, A., Kolaç, N., \& Erol, S. (2013). Bir İlköğretim Okulu 4, 5, ve 6. Sınıf Öğrencilerinin Saldırganlık Düzeylerinin Anne Baba Tutumları ve Bazı Değişkenler ile İlişkisi. Marmara Üniversitesi Să̆llk Bilimleri Enstitüsü Dergisi, 3(4), 184-190.

Solmaz, B., Tekin, G., Herzem, Z., \& Demir, M. (2013). İnternet ve Sosyal Medya Kullanımı Üzerine Bir Uygulama. Selçuk Illetişim, 7(4), 23-32.

Soylu, Y., \& Kağnıcı, D. Y. (2015). Evlilik Uyumunun Empatik Eğilim, İletişim ve Çatışma Çözme Stillerine Göre Yordanması. Türk Psikolojik Danışma ve Rehberlik Dergisi, 5(43), 44-54.

Şahin, S., \& Aral, N. (2012). Aile İçi İletişim. Ankara Sağlık Bilimleri Dergisi, 1(3), 55-66.

Taylor, S. E., Peplau, L. A. \& Sears, D. O. (2007). Sosyal Psikoloji (Çeviren: Ali Dönmez). Ankara: İmge Kitabevi.

Thomas, K. W. (1976). Conflict and Conflict Management. M. D. Dunnette içinde, Handbook of Industrial and Organizational Psychology (s. 889-935). Chicago: Rand McNally.

Tutarel-Kışlak, Ş., \& Çavuşoğlu, Ş. (2006). Evlilik Uyumu, Bağlanma Biçimleri, Yüklemeler ve Benlik Saygısı Arasındaki İlişkiler. Aile ve Toplum, 3(9), 61-68.

TÜİK. (2016). Aile Yapısı Araştırması-2016. 01 26, 2017 tarihinde Türkiye İstatistik Kurumu Haber Bülteni: http://www.tuik.gov.tr adresinden alındı

Twenge, J. M., \& Campbell, W. K. (2010). Asrın Vebası: Narsisizm Illleti. (Ö. Korkmaz, Çev.) İstanbul: Kaknüs Yayınc1lık.

Worden, M. (2013). Aile Terapisi: Temelleri. (T. Akbaş, Çev.) Adana: Nobel Kitabevi.

Yıldırım, A., \& Şimşek, H. (2008). Sosyal Bilimlerde Nitel Araştırma Yöntemleri (6. Baskı). Ankara: Seçkin Yayıncılık.

Yıldız, M. A., \& Baytemir, K. (2016). Evli Bireylerde Evlilik Doyumu ile Yaşam Doyumu Arasındaki İlişkide Benlik Saygısının Aracılığı. İnönü Üniversitesi Eğitim Fakültesi Dergisi, 17(1), 67-80. 


\section{EK 1: GÖRÜŞME FORMU (ANNE-BABA)}

Cinsiyetiniz: Yaşınız: Mesleğiniz:

\section{Sorular}

1. Eşinizle hangi konularda anlaşmazlık yaşarsınız?

1.1.Yaşadığınız bu anlaşmazlıklarda tepkiniz nasıl olur?

2. Çocuğunuzla hangi konularda anlaşmazlık yaşarsınız?

2.1.Yaşadığınız bu anlaşmazlıklarda tepkiniz nasıl olur?

\section{EK 2: GÖR ÜSME FORMU (ÇOCUK)}

Cinsiyetiniz: Yaşınız: Sınıfınız:

\section{Sorular}

1. Anne ve babanızla hangi konularda anlaşmazlık yaşarsınız?

1.1. Yaşadığınız bu anlaşmazlıklarda tepkiniz nasıl olur? 